\title{
Digital Technologies and Their Application in a Child's Life
}

\author{
Žaneta Gužíková - Simona Chicevič - \\ Dušan Kostrub - Sylvia Brychová*
}

Received: October 6, 2021; received in revised form: October 17, 2021; accepted: October 18, 2021

\begin{abstract}
:
Introduction: This research aims to examine pedagogically significant applications of digital technologies and attempt to identify certain principles of educational influence in pre-primary education. A qualitative methodology was used for this purpose.

Methods: The research is focused on in-depth interpretive analysis and identification of the meanings of the use of digital technologies for didactic purposes from a pedagogical point of view. The research was conducted in a kindergarten in Šal'a, Slovakia; the research group consisted of 12 children aged 5-6 years and 10 parents of children of preschool age from 3 to 6 years.

Results: The results have shown that through the constant comparative strategy and the sampling of extreme and similar cases we were able to analyse particular occurrences and mutual connections between them as interpreted by children and parents.

Discussion: We know that there are disagreements and conflicts between parents and children in the area of using digital technologies by children. In the application of digital technologies, we see not only a typical feature of contemporary society's behaviour (communicating, presenting, etc.) but also certain support of development-forming aspects of children's personalities.

Limitations: The research was conducted during the COVID-19 pandemic when the kindergartens were attended by a limited number of children. The interviews with parents were carried out online without a closer social contact.

Conclusion: We identified identical and non-identical categories in opinions between children and parents relating to the use of digital
\end{abstract}

\footnotetext{
" Žaneta Gužíková, Comenius University in Bratislava, Faculty of Education, Bratislava, Slovakia; guzikova2@uniba.sk

Simona Chicevič, Comenius University in Bratislava, Faculty of Education, Bratislava, Slovakia; chicevic1@uniba.sk

Dušan Kostrub, Comenius University in Bratislava, Faculty of Education, Bratislava, Slovakia; kostrub@fedu.uniba.sk

Sylvia Brychová, Comenius University in Bratislava, Faculty of Education, Bratislava, Slovakia; brychova@uniba.sk
} 


\section{Acta Educationis Generalis \\ Volume 12, 2022, Issue 1}

technologies by children. We discovered that parental educational principles related to the use of digital technologies are opinion-determined.

Key words: preschool children, parents, digital technologies and their use, unifying education, educational perspectives.

\section{Introduction}

Digital technologies are an inseparable part of contemporary children's lives. Children participating in preschool education use digital technologies daily not only as part of the educational process but also at home; they are also regularly used by their parents as a normal part of family life. The learning activity of a child is not solely dependent on a teacher. Whatever a teacher may do during teaching, his/her activities and communication are influenced by an intervening variable - the child and his/her individuality (Mešková, 2012). To be able to communicate their experience and knowledge to others, children must be accepted by their teachers as equal partners; this way we (as teachers) enable their personal development and allow them to become open to new knowledge. What it means is that we enable children to make mistakes, to have doubts and dilemmas, but on the other hand, to construct acceptable explanations from their perspective of understanding (Tóthová, Kostrub, \& Ferková, 2017), to acquire knowledge from sources while verifying it critically, to ponder it, to validate their sources and to join individual pieces to form a meaningful whole. To be able to learn all this, a person must do it independently (Spitzer, 2014). Knowledge is of an intersubjective character and is constructed by a child in the realm of the social world in which the child is living (Štech, 1992). As a mental base of human behaviour and the person's (child's) relationship to the world, knowledge is a network of convictions, meanings, beliefs, and attitudes (Kolláriková et al., 1997). Teaching should contribute to a qualitative change in the understanding of various occurrences. It should not offer ready-made knowledge but rather activate constructive processes in the child's mind. According to the constructivist model of teaching, the education should be designed to allow each child to construct his/her knowledge, "to create it as a protagonist who utilises all the previous knowledge and experiences (Tóthová, 2014). An educational activity (and its overall context) is a private matter of a teaching/learning group (children/pupils/students and their teacher); it excludes the possibility to be prepared ("dictated") in advance by someone other than the concerned - children/pupils/students and the teacher (Kostrub, Severini, \& Rehúš, 2012). Even if a child performs an individual activity, an emphasis must be placed on mutual social interactions while we must not forget the risk of neglecting the child's individuality (individual processes of cognitive change). Children learn better if the process is interactive and rich in various contexts. This helps to stimulate discussions between children, to develop children's 


\section{Acta Educationis Generalis \\ Volume 12, 2022, Issue 1}

understanding of (and "penetration" into) human intentions, and through it, into various interpretations of activities induced by a certain occurrence (Kostrub, 2008). This interpretation of knowledge and learning quite naturally includes the category of critical thinking (Kolláriková et al., 1997). According to the authors Paul and Elder (2010, as cited in Kosturková \& Ferencová, 2019), a cultivated critical thinker has the following features: he/she poses essential questions and problems and formulates them clearly and precisely; collects and evaluates relevant information; arrives at well-founded conclusions and solutions and tests them through appropriate criteria and norms; thinks openly within alternative systems of thinking and based on a need, assesses assumptions and consequences; while solving complex issues, he/she communicates effectively with others. Sitná (2013) states that through an active approach to acquiring new information, children also effectively develop their critical thinking skills. These subjects utilise (mainly) their ability to identify important information and the ability (mainly) to find information in a (teaching) unit. A culturally literate child is (Kostrub et al., 2018): 1) A resourceful child - a child can adequately react to an intellectual challenge; accept a challenge, react to it in his/her typical style and use it to his/her advantage. He/she manifests an attitude of natural curiosity - wants to know the outcome of a situation, of his/her action, and also how the outcome is going to be accepted. A resourceful child has a sharp eye. 2) A prepared child - a child that successfully manages and controls a particular situation. $\mathrm{He} / \mathrm{she}$ can face it in an expected and acceptable manner. $\mathrm{He} / \mathrm{she}$ manifests an attitude of natural interest in an activity and is target-oriented. 3) A self-sufficient child - a child that acts independently (with minimal or no outside help) based on his/her judgement and bears adequate responsibility for his/her actions. He/she manifests an attitude of natural vigour. 4) A cooperating child a child that can make social contact with others, maintain it, change it or finish it. He/she manifests an attitude of natural social inclination and enjoys doing activities with others, getting results from common activities, and appreciates the feeling of shared joy. A competent child is a child proceeding on at least three levels: a) on the level of his/her development, b) on the level of the educational process, c) on the everyday-life level (in situations life brings). A competent child is a child that can manage various situations. Those familiar with the issue agree with the statements of contemporary educators and psychologists: what children learn in class depends on what they know already (Kasíková, 1997). Everything a child acquires, knows, does, and uses in this stage of life influences his/her successes and failures in further life stages (Uváčková, Valachová, Lehotayová, Leginusová, \& Bruteničová, 2012). We embrace the idea that digital technologies belong in children's hands as they provide them with unique opportunities for new, up-to-date, and attractive learning, opportunities to search for, communicate and explore big ideas (Kalaš et al., 2013), they are a part of everyday life of preschool children and often make life easier, enhance communication with family and friends (Holloway, Green, \& Stevenson, 2015). 


\section{Acta Educationis Generalis \\ Volume 12, 2022, Issue 1}

"Digital media" and "technologies" are considered inclusive terms, reflecting a scale of sources available in early education (Plowman, 2016, as cited in Arnott, 2017). Their inclusion in children's everyday life and learning has changed the understanding and thinking about childhood (Arnott, 2017). Murcia, Campbell and Aranda (2018) claim that digital technologies can include social media, online games and applications, multimedia, applications for productivity enhancement, cloud computing, interoperable systems, and mobile devices. Digital learning is also defined as any type of learning that is facilitated by technology or by instructional practice that effectively employs technologies. Digital learning appears in all learning spheres and domains. It incorporates a wide spectrum of procedures including mixed and virtual learning, game learning, access to digital content, cooperation on a local and global level, sending messages, active participation in online communities with the help of technologies, cooperation, creation and management of online environments (e.g. Severini, Kožík Lehotayová, \& Csandová, 2020; Jančaříková \& Severini, 2020). It was Papert who started thinking about children, not teachers. He pointed out that a computer is not the teacher's tool; it is the child's tool (Kalaš et al., 2013). The application of digital technologies starts in childhood, from an early age; this fact is interpreted by some scientific studies (Kotilainen, Suoninen, Walamies, \& Tuominen, 2011). It seems that parents' activities and their relationship to media influence subsequent activities of their child (Kotilainen, Suoninen, Walamies, \& Tuominen, 2011). Children's interest in digital technologies is considered crucial (Undheim \& Jernes, 2020); we consider teachers' erudition in the area of digital technologies that enter the teaching process equally important. Learning is an activity seeking a balance between developing the structure of the mind and newly arriving knowledge based on a lasting principle. The mind's content is inherent in the beginning but over time, through different mechanisms, it adjusts to the environment and various external influences the child is trying to understand. According to J. Piaget, knowledge cannot be transferred onto children. Parents and teachers can, however, aid the creation of conditions and situations when children construct pieces of knowledge themselves and actively integrate them into their system of knowledge (Kalaš et al., 2013). The presence of technologies in all aspects of our lives can be connected with changes when it comes to how we construct and share knowledge (Arnott, 2017). Digital technologies offer many opportunities for formal, non-formal, and informal learning and thus create a productive environment and copious opportunities for the learning process (Kalaš et al., 2013). An exceptional critical moment is the child's/children's powerlessness during digital technologies malfunctioning, which contradicts the claim that contemporary children are labelled digital natives (Tóthová, Kostrub, \& Ferková, 2017). Only a few scientific studies deal with the risks and benefits of using digital technologies by preschool children. Current recommendations related to the use of digital technologies, based on the passive use of digital 


\section{Acta Educationis Generalis \\ Volume 12, 2022, Issue 1}

technologies, which state that the time spent at the screen is harmful, are at odds with the advice of educational experts and application developers who view the interactive time spent at the screen as engaging and educational (early childhood educational guidelines support the development of skills in the area of digital literacy) (Holloway, Green, \& Stevenson, 2015). What we see as the key prerequisite for acquiring the skill of critical use of digital technologies is the development of digital literacy. Kalaš et al. (2013) characterize digital literacy as a collection of knowledge and understanding necessary for reasonable, safe, and productive use of digital technologies for learning either at work or in everyday life. It is a set of skills that incorporates: meaningful and creative use of various digital tools for own needs, learning, self-expression, and own complex personal development; effective solution of tasks and problems in the digital environment; qualified choice and ability to use appropriate digital technology to find information, process, use, share or create this information; critical assessment and analysis of knowledge acquired from digital sources; understanding the social consequences (including safety, privacy protection, and ethics) occurring in the digital world; appreciating and having the need to continually develop these skills and learn more. Interacting with digital sources suggests that a game should be the central part of their use (Arnott, 2017). As a result, the implementation of digital tools and toys should not be compared with established toys; such comparisons, therefore, often devalue digital toys, labelling them as too individualistic, lacking creativity, and inducing no motor reactions. He claims that the digital game should be considered in a wider context from the cultural aspect; that is to consider how technologies connect children with contemporary society. The implementation of digital tools creates new types of games with their new opportunities and needs for development, which must be assessed individually and not necessarily as being of lower quality when compared to more familiar toys. For example, Murcia, Campbell \& Aranda (2018) mention that an initiative of the Australian government instigated a reform of the educational system and encouraged educators to see opportunities in the fact that digital technologies can support active learning and improve the teaching process itself. Kostrub, Severini and Rehúš (2012) state that being active is justified when it enables the learner to overtake the active role (the apply his/her activity): to search, explain, observe, start discussions, participate in simulations, etc. and not when the learner is supposed to listen, fill worksheets or get engaged in routine discussions with the teacher. We must support the need for critical reflection on the use of digital technologies by children. 


\section{Acta Educationis Generalis \\ Volume 12, 2022, Issue 1}

\section{Methodology}

The aim of this qualitative research is to discover and develop a theory, which arises from the research context and not from deductive processes supported by the verification of the initial theoretical framework. Based on this idea, we constructed a design of the qualitative research (e.g. Kostrub, 2016; Severini \& Kostrub, 2018). The decision to conduct qualitative research is not self-serving but is determined by the focus of our research, i.e. parents and children and their opinions. We examined the structures of meaning related to digital technologies and their role in children's lives, which the participants of our research actively create, communicate, and are also disposed to describe and explain. Qualitative research enables us to ponder human behaviour from the perspective of the protagonist or more precisely, from the internal (subjective) reality, the reality we are aware of and experience. The research aims are: to identify children's and parents' opinions related to the use of digital technologies for children's education; to study and interpret views of the educational process in connection to digital technologies from the perspective of our research participants; to determine the presence of educational principles in the use of digital technologies by our participants. These aims are derived from the known educational reality.

\subsection{Participants}

The research group consists of 22 participants from the Slovak kindergarten twelve children, one child aged five, eleven children aged 6, and ten parents: four mothers of children aged 3, two mothers of children aged 4, two mothers of children aged 5, one mother of a child aged 6 , and one father of a child aged 3 .

All participants had been asked to participate in the research in advance, and they manifested their willingness to be part of it. The participants had been assured that all rights related to maintaining anonymity in connection with the ethics of the research would be followed. The parents of children participating in the research had been acquainted with the research objectives and agreed with their children's inclusion in the research sample.

\subsection{Research problems}

While formulating the research problem, we derive from the observed reality that there are inconsistencies in parents' and children's actions related to the use of digital technologies; confrontations are initiated as well as lengthy discussions, orders, and restrictions related to the use of digital technologies by children are imposed. There is an evident lack of harmony, parents impose restrictions on the use of digital technologies by children, children demand (often forcefully) the use of digital technologies; parents sometimes force children to use digital technologies. The backdrop of these externally visible and perceived manifestations and it is, therefore, difficult to judge the correctness, appropriateness (justification), or meaningfulness of this behaviour. We need to 


\section{Acta Educationis Generalis \\ Volume 12, 2022, Issue 1}

know the background of such behaviour mainly to understand and accept it but also to use it in the ongoing or follow-up educational activity.

\subsection{Research objectives}

In collaboration with participants, to detect and interpret the role digital technologies play in the lives of participants. What is behind their decisions in situations in which digital technologies are used? The reason we conduct the research is to identify various perspectives of seeing the application of digital technologies by these two groups of participants; to find out if (how or why) they are identical or contradictory. The research objectives are to identify the potential of the child in connection with the use of digital technologies in the educational process in the socio-constructionist model of teaching, conceptualize the pedagogical aspect of the application of digital technologies and clarify more efficient use of digital technologies in pre-primary education.

\subsection{Research questions}

In our research we stated the following research questions:

RQ1 Which digital technologies do our research participants (children) have at their disposal?

RQ2 What role does digital technologies play in our participant's (children and parents) lives?

RQ3 How do participants (children and parents) use digital technologies in the educational process?

RQ4 Is it possible to identify any educational principles in the use of digital technologies by research participants (parents)?

\subsection{Data collection}

To get detailed information related to identifying children's and parents' opinions related to the use of digital technologies for children's education, the data were collected via unstructured and semi-structured interviews and the focus group, unstructured observation, participatory observation, nonparticipatory, direct, and indirect observation. For the unstructured interview, open-ended questions were asked while reacting to the interview's progress. Questions were not prepared in advance. For the semi-structured interview, a content framework and areas of questioning were prepared, but they were adjusted to the interview's progress. The discussion in the focus group was moderated by the researcher. The group interaction was used to acquire data related to the topic along with the participants' views, which would not be as accessible outside the group.

Interviews with parents took place online through digital communication technologies, Facebook, Messenger as a result of the world situation related to the COVID-19 pandemic. The interviews were recorded using a dictaphone. Discussions were held several times as we wanted to make sure our 


\section{Acta Educationis Generalis \\ Volume 12, 2022, Issue 1}

understanding of the stated ideas was correct. During the analysis of the research material, individual categories were gradually formed and their saturation was increasing. Step by step, a unified picture started to appear, based on which we were able to draft a conceptual map and subsequently construct our interpretation.

The interpretations obtained from the participants were transcribed into a text form, we worked with the transcript, which we analysed, examined, and compared the individual data. The data were categorized into groups - categories that are created based on common properties or characteristics. The categories were merged or developed as needed and marked with codes for easier orientation. An interpretation of the findings was created based on the interconnectivity of individual categories as well as conceptual maps.

\section{Findings}

Based on the research material and the analysed data we formulated 15 primary categories:

1. A tool for personal help;

2. Knowing and using the functions of digital technologies;

3. A tool for the child's entertainment;

4. A communication tool;

5. A tool for learning and teaching;

6. A tool for finding directions;

7. A tool for acquiring information;

8. A tool for exploration;

9. A tool for technological progress;

10. A tool for preserving the past with the possibility of return;

11. A tool for self-presentation;

12. A tool for securing reassurance;

13. The safety of use;

14. The external regulation of the use of digital technologies;

15. The external explanation of the media content.

In this part, we present the findings of the research by identifying identical opinions of children and parents (Figure1) related to the use of digital technologies in education. In the category A tool for learning and teaching (NU), children interpreted the topic as follows: "... we are learning.", "Well, because it helps me with English.", "When we were working on the computer, I put there a circle and a square and that's what we were learning..." They see the use of digital technologies and similar tools as the support of learning and teaching. Parents consider digital technologies a common part of children's lives and a tool for learning that leads children to acquire new knowledge: “... and from that, she learned a lot of English.", "And she learns it spontaneously." In addition, what parents see as important is to search for content that helps children acquire new competencies and knowledge: "It leads them toward 


\section{Acta Educationis Generalis \\ Volume 12, 2022, Issue 1}

independence.", "When she wants to watch something I find something where she can find some ... ", "... so the child can watch programs that would educate."

The category A tool for acquiring information (NI) helps us to see digital technologies as a tool for exchanging experiences and other information (textual or pictorial) that the children consider important: "For example, to look for information, what you want to know.", "And you look at a watch when you want to know what time it is ...", "Or mum finds there what she wants to cook, how to make it, what goes in and then she makes it." Parents see digital technologies as a valuable tool for acquiring information for children and thus help them to progress. At the same time, they see digital technologies as a great accessory to their educational influence when they claim that digital technologies provide children with richer content than they would be able to offer alone: “... there are definitely some intelligent applications or games or whatever that may help with progress ...", "It is surely richer than what I would be able to give.", "In my view, it is clearly beneficial from this point of view."

Children see progress in digital technologies as an ongoing improvement of already used machines and objects from their surroundings: “... for improving transportation and electronic systems in cars.", "When something is invented, they improve it." It is integrated into the category A tool for technological advancement (NTP). Parents, on the other hand, see progress in digital technologies as a possibility for children to acquire necessary information much faster than before and thus progress much faster than in the past. They see great potential in what digital technologies can bring their children: "And the progress is very fast and is picking up speed ...", "Well, I believe that taking advantage of the potential is the duty of our generation in order for children to develop the potential...", "There is potential in this direction too and we need to take advantage of it...", "human science and research and evolution and human intelligence, in general, are quickly developing, at a really high speed."

Children see activities connected with the use of digital technologies as entertaining, and they often solve really complex problems, which is most entertaining. This is included in the category A tool for child's entertainment (NZ) which they interpret: "If I'm bored and my mum does not allow me to use the tablet, I take my phone, I only have a few games there but I enjoy them... ", "That you have it with you and you use it for playing." They use digital technologies to relax, entertain themselves and while doing so, they feel joyous. We claim that the most effective learning occurs when we enjoy what we are doing at the moment. Parents interpret digital technologies as a tool for their child's entertainment the following way: "Only to a small extent as a form of entertainment.", "It is for him something like joy, entertainment from time to time.", "She also has games on the tablet...", "She enjoys listening to it." Parents see the use of digital technologies as a sort of substitute for parental 


\section{Acta Educationis Generalis \\ Volume 12, 2022, Issue 1}

attention: "... the easiest application is to use it as a babysitter, that the child sits with it and you can do your own thing." The majority of parents see this as a negative feature and do not use digital technologies for this purpose: “... for example, some children watch YouTube on their phones so that the parents can be free...", "Because the reason is that parents get rid of children for a while. He/she wants to have peace and quiet and simply gives the child a mobile."

The use of digital technologies brings not only positives but has some risks as well. Children are aware of the risks and talk about them in the category The safety of use (BV): "But they are not always good for us. When we use them for too long, we can have a headache. Or our eyes can get damaged." What parents see as risky are mainly the changes of behaviour caused by watching inappropriate content, by the desire to repeatedly escape into a virtual world and they also see danger in the prolonged sitting, which may lead to physical consequences: "If she watches something inappropriate, she has strong manifestations ...", " ... then she behaves terribly.", "At the same time, I see it as an escape into a virtual world...", "it offers these children a huge space where they start living parallel lives, fictitious, virtual lives and it scares me.", "... then it results in various behavioural disorders", "... not only did she damage her back or her wrist..."

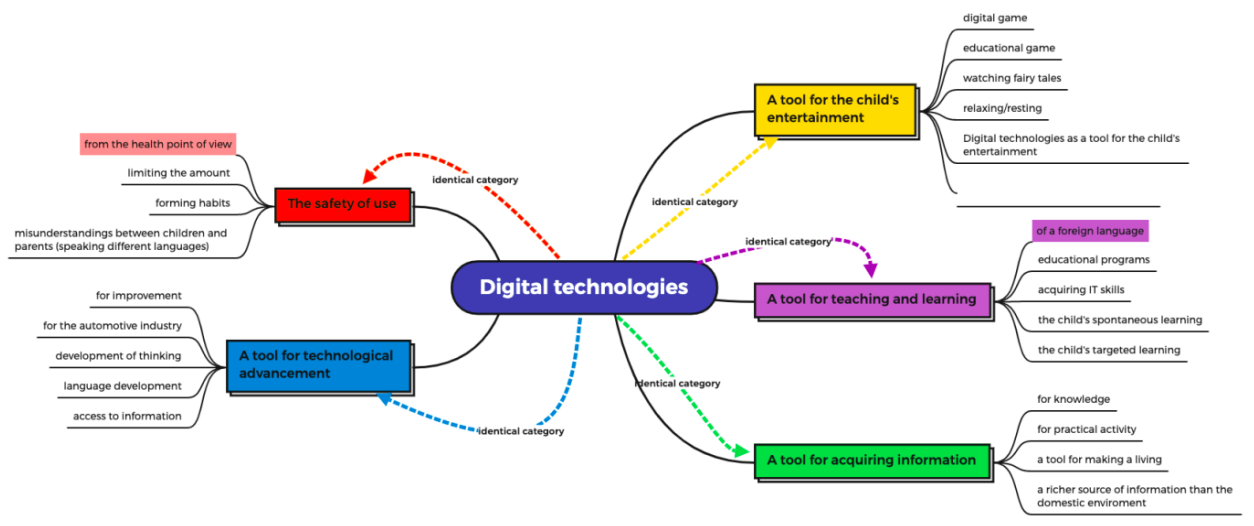

Figure 1. The conceptual map with identical categories and subcategories.

A tool for personal help (NOP) is among the non-identical opinion interpretations that were collected from children but not from parents (Figure 2). This proves the fact that digital technologies are used for personal benefit in everyday situations. Children explain the specific qualities of digital technologies: "It serves me in a way that I have a bracelet and there I have the house number in case I forget, the telephone number, also I have the house number there ...", "To call my daddy if something happens to me at the playground..." Children were aware of the usefulness of digital technologies, 


\section{Acta Educationis Generalis \\ Volume 12, 2022, Issue 1}

they understand their functions (PVFDT) and describe them as follows: "When you have digital technologies such as a notebook, you can put photos there, then you place it on the desktop, send it somewhere, I do not know where it is sent and then they send it to your house and you have photos." Digital technologies have changed the way we communicate, and children communicate with loved ones through various channels. Face-to-face communication was replaced by long-distance communication - it is accessible, effective, reliable, and commonly used by children. It is identified through the category A communication tool (NK). "Because, for example, it is shown, but the photo is still there and I can still make a call.", "Or, on the phone, I can send a message that I had, for example..." Orientation in an unknown environment and finding directions is facilitated by digital technologies as A tool for finding directions (NUO): "And I also have there a car finder, that I type a name in there and it's a car finder and it will show where mum and dad are.", "We are looking for the way to a place we have never been to, so it will show us in the car which way we should go." When needed, these types of tools are commonly used. Digital technologies also provide users with more freedom, autonomy, and opportunities to explore something new while it leads to a more effective solution of problems: "...those applications where you click, it opens, and you know what type of mushroom it is. You point at the mushroom and it shows you if you can eat it. But it's not written, it only shows you a picture." It is part of the category A tool for exploration (NS). Going back in time and restoring memories through digital technologies is another application the children are aware of: "For recording videos when we are on a holiday so we would know where we had been, what we did there.", "In such a way that when you have those digital technologies such as a notebook, you put photos there ..." This application of digital technologies forms the category A tool for preserving the past with the possibility of return (NUM). Digital technologies can also be used as A tool for self-presentation (NSP) where a child acquires a view of oneself, space, and the ability to think of oneself, to "look" at oneself with someone else's eyes. "And when he wants, he records his songs on the guitar and plays them back to me or mum and then puts them into the computer and on the Internet so others can hear them too." Digital technologies are also A tool for securing reassurance (NZU) where the human need for assurance is fulfilled: “... then my mum put there (into a watch) the house number, the phone number, the police number 112. Then she put mum and dad's numbers there, the whole family...

We see digital-generation children as very pragmatic and practical individuals who are aware of the capabilities of digital technologies and who use them not only for entertainment and fulfilment of their own needs but also as a tool of personal help, communication, learning, teaching, finding directions, acquiring information, exploring, preserving the past with the possibility of return, selfpresenting and acquiring assurance. 


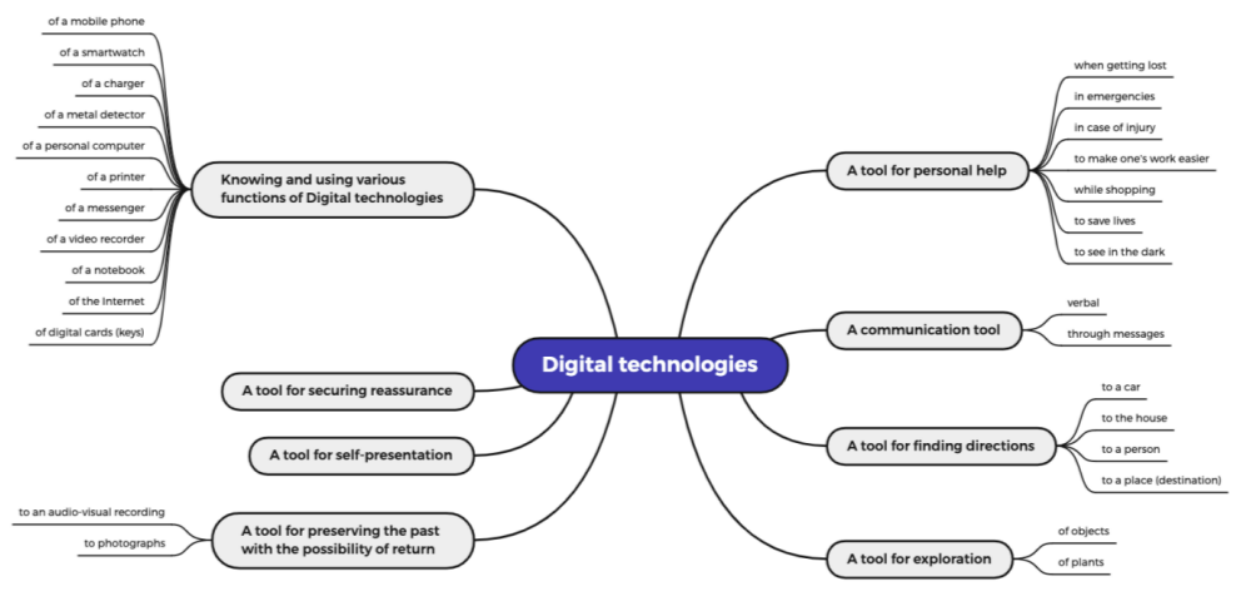

Figure 2. The conceptual map with categories and subcategories collected only from children.

The study also contains categories representing parents' opinions that are not identical with the opinions of children (Figure 3). The first non-identical category is the External regulation of the use of digital technologies (ER). Here, parents see it as necessary to regulate the following parameters. The content: "To watch out for what he watches.", "But he only watches programs for children.", "To have it under control, what the child watches there." The length of the content consumption: "I tell him, you have an hour for this...", "... at the same time it must be rationed." The time when a child may use digital technologies: "Not now, now is not the time for TV.", "... when the time is right. So, not before sleep..."

Parents believe that answering children's questions while they consume digital content is important, the same applies to explaining (and further explaining) the content (EZ): “...we explain to her what is going on there, why something has happened.", "Now, she herself has questions and asks. Why this and what does this mean and we are there and we explain right away so she understands everything correctly...", "We are with her, we explain and further explain...".

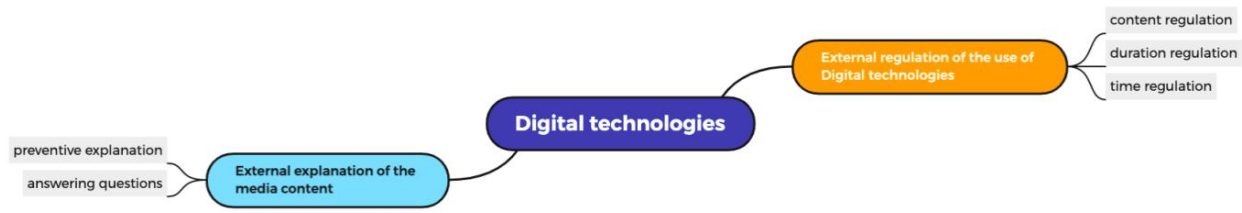

Figure 3. The conceptual map with categories and subcategories collected only from parents. 


\section{Acta Educationis Generalis \\ Volume 12, 2022, Issue 1}

The frequency of occurrence is recorded in the following tables (Table 1, Table 2) containing particular categories, the order of occurrence, individual codes, and the recorded frequency:

Table 1

\begin{tabular}{|c|c|c|c|}
\hline Order of & Category & Code & Frequency of \\
\hline occurrence & & & occurrence \\
\hline 1. & $\begin{array}{l}\text { Knowing and using the functions of digital } \\
\text { technologies }\end{array}$ & PVFDT & 18 \\
\hline 1. & A tool for personal help & NOP & 18 \\
\hline 2. & A tool for the child's entertainment & NZ & 15 \\
\hline 3. & A communication tool & NK & 7 \\
\hline 4. & A tool for finding directions & NUO & 6 \\
\hline 5. & A tool for learning and teaching & NU & 5 \\
\hline 6. & A tool for acquiring information & NI & 3 \\
\hline 7. & A tool for exploration & NS & 2 \\
\hline 7. & A technological advancement tool & NTP & 2 \\
\hline 7. & $\begin{array}{l}\text { A tool for preserving the past with the } \\
\text { possibility }\end{array}$ & NUM & 2 \\
\hline 8. & A tool for self-presentation & NSP & 1 \\
\hline 8. & A tool for securing reassurance & NZU & 1 \\
\hline 8. & The safety of use & $\mathrm{BV}$ & 1 \\
\hline
\end{tabular}

Table 2

\begin{tabular}{|c|c|c|c|}
\hline Order of & Category & Code & Frequency of \\
\hline occurrence & & & occurrence \\
\hline 1. & $\begin{array}{l}\text { External regulation of the use of digital } \\
\text { technologies }\end{array}$ & $\mathrm{RE}$ & 18 \\
\hline 2. & A tool for the child's learning and teaching & NU & 15 \\
\hline 3. & A technological advancement tool & NT & 7 \\
\hline 4. & A tool for the child's entertainment & NZ & 6 \\
\hline 4. & The safety of use & $\mathrm{BV}$ & 6 \\
\hline 5. & A tool for acquiring information & NI & 5 \\
\hline 6. & External explanation of the media content & EZ & 3 \\
\hline
\end{tabular}

\section{Discussion}

Based on the research, we found identical categories between parents and children, among which several categories were identified, such as digital technologies as a tool for children's entertainment, digital technologies as an 


\section{Acta Educationis Generalis}

Volume 12, 2022, Issue 1

educational tool, a tool for acquiring information, a tool for technical progress or the safety of use. In the description of the educational reality, a full understanding has been observed, which means that a parent is aware of the reason why to offer a child a digital technology tool, and the child is aware of the reason why he/she wants it. In other words, for example, the child is entertaining himself/herself and the parent is fully aware that in that particular time the child uses digital technologies for entertainment. But, according to the identical categories, the parent is also able to distinguish between mere entertainment and a process of education. The child does not manifest resentment if his/her opinion matches that of the parent and vice versa. We see it as pedagogically justifiable to know parents' opinions of children's use of digital technologies while we consider understanding children's opinion of their own usage of digital technologies in different parts of the day, various situations, and activities equally important. Through the application of digital technologies, a part of life opens for the child that has a contemporary-cultural as well as a personality-updating character. Parents considered it necessary to regulate the length of time when children consume the content of digital technologies and to explain and further explain the content. Both children and parents view digital technologies as a tool for the child's learning but parents also use them as a sort of substitute for parental attention. To a certain extent, they also see the use of digital technologies by children as a threat; this fact was mentioned by one of the children as well. Children recognize digital technologies as a normal part of everyday life and are aware of their effective utilisation not only as a source of entertainment but mainly as a tool for solving problems and for personal help. Unlike parents, children do not consider digital technologies expressly harmful or dangerous, what they mostly talk about are the possibilities of their effective use. For children, digital technologies are a communication tool (through voice or messages), a tool for finding directions to a car, home, to a person or place (destination), for learning and teaching foreign languages through available educational programs, a tool for acquiring information to extend their knowledge but also to find instructions for practical activities, a tool for exploring objects or plants, for preserving the past with the possibility of a return to audio-visual recordings or photographs, for self-presentation, for technological progress in the automotive industry and overall improvement.

We determined the following educational principles that parents actively apply during their educational influence related to the children's use of digital technologies: the principle of systematic behaviour is applied by participants mainly for the purpose of children's education. We encountered repeated and targeted playing of educational programmes for children or music videos to help children develop certain skills, for example, math or improve foreign language fluency. Parents also repeatedly employed the principle of activity when they encouraged children to use digital technologies, for example, to sing along with professional singers, to repeat foreign language words (mainly in English) but 


\section{Acta Educationis Generalis \\ Volume 12, 2022, Issue 1}

this way, they also encourage children to use digital technologies independently and thus become their active users. The demonstrative principle is used by parents when they want to demonstrate to children how to use digital technologies in a suitable way; they become exemplary users of digital technologies. Parents are aware of being imitated by their children and that this applies to digital technologies as well; parents consciously work with this knowledge. We believe that this finding determines and conditions parents' overall behaviour. One of the most discussed and applied educational principle was the principle of reasoning when the form and content of digital technologies play an important role. Parents take into consideration the developmental and individual features of their children and use digital technologies appropriate to that knowledge. At the same time, parents see digital technologies as an important technological advancement tool and they want their children to be in everyday contact with digital technologies as they realise their importance for contemporary life. Children, on the other hand, look at digital technologies as a tool for technological advancement through which the world improves and progresses. Parents, however, are also worried about all possible risks of digital technologies including physical and psychological consequences. We were surprised by a bifurcated stratification of opinions in the category A tool for entertaining the child when in some cases, parents considered it suitable to use digital technologies as a substitute for parental attention. They use digital technologies as a sort of babysitter when they do not have enough time or space to pay attention to their children. Contrary to that, the majority of parents are against using digital technologies to entertain children in this way and consciously do not use digital technologies for this purpose.

What we consider vital is the parents' deeper understanding of the role of digital technologies and the fact that they want to understand why children are interested in digital technologies (when it comes to the content as well as the extent of their use). Another thing we appreciate is the mutual discussion preceding the formulation of rules and the explanation of the content that led to greater consistency of parents' and children's interpretations. There are also agreements between children and parents related to the use of digital technologies which subsequently result in a more meaningful utilisation of digital technologies by children. It was found that children's application of digital technologies also depends on what they learn from their parents; children observe parents' attitudes towards digital technologies. Parents need to consciously set themselves rules when it comes to using digital technologies, discuss the possibilities of using digital technologies with children, participate in mutual educational programs with children and see digital technologies as being a part of everyday life (including children's lives). Children consider digital technologies an important tool for creating social interactions with parents, peers, or relatives for feeling reassured about their closeness, and thus parents need to understand that digital technologies have become an inseparable part of 


\section{Acta Educationis Generalis \\ Volume 12, 2022, Issue 1}

children's lives and that children see them as an important tool for communicating with each other as well as with parents.

What was an interesting finding for us was the children's naturalness in interpreting their use of digital technologies while referring to digital technologies as a tool for personal help when being lost, in case of an injury, for making one's work easier, while shopping, when saving lives, seeing in the dark or in emergencies. We aimed to fully describe and interpret the findings from material acquired from the field (Figure 4). Through reliability, credibility, and an audit, an assessment of the process and quality control of a cross character was conducted. We consider the results acquired through our research valuable mainly because we managed to identify relationships between the research phenomena and the individual categories. At the same time, thanks to the process of their acquiring and elaboration, we see them as methodologically transferable.

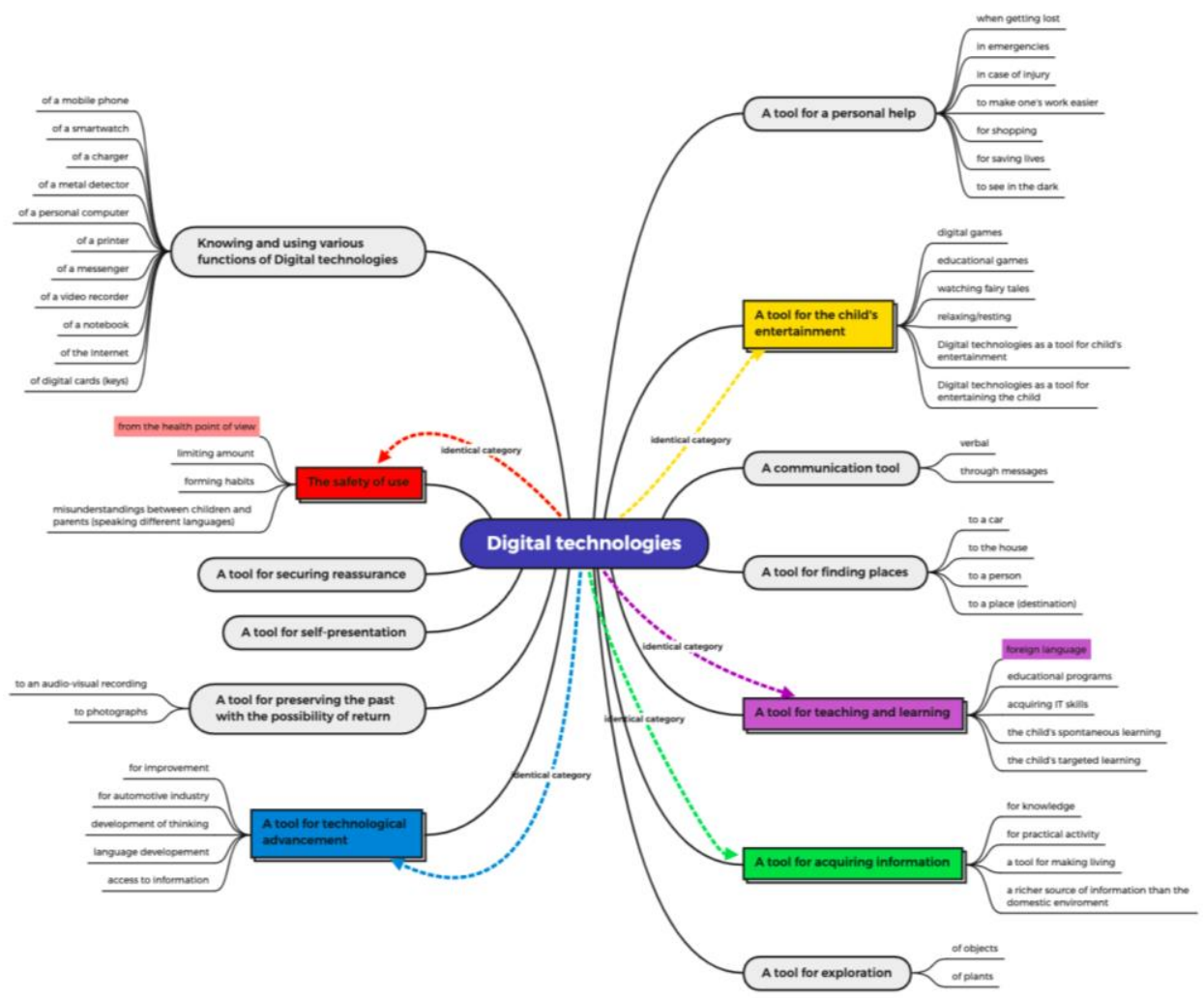

Figure 4. The conceptual map depicting all identified categories and subcategories occurring in the research.

What we found surprising was that during interviews when asked about digital technologies, children mentioned no digital games that were freely available as 


\section{Acta Educationis Generalis \\ Volume 12, 2022, Issue 1}

part of the educational process in the kindergarten. According to them, digital technologies are a mobile phone, a TV, an iPhone, an MP4, an electric car, a digital watch, a smart-watch, a charger, a tablet, a metal detector, AirPods, GPS, a cash machine, a printer, a copier, a video recorder, a digital camera, digital cards, a scanner, a reader. They consider them " $\ldots$ something we use very often ..." a product of human culture, co-creating the society and the lives of all people. As a result of our research and compliant with the opinions of participants, we see digital technologies as technical tools for learning and teaching and, at the same time, as a part of human culture - two equal and mutually interdependent factors, which are an integral part of the world's progress.

\section{Conclusion}

Our further research will focus on the creation of borders and maintaining limits related to the use of digital technologies by children in their domestic environment. We will concentrate on the application of concrete principles used at home in communicating with children participating in obligatory preschool education. In further research, we will create a conceptual map as a result of action research, by which we will gain an understanding of how the participant (child) constructs the "social reality" in the field of digital technologies. A complete meaningful picture will be created for us, which will be the result of a phenomenological type of qualitative research and in which the participant has integrated its own experience with the acquired knowledge and values of the given society. Its content will be a description of identified relationships, connections between them, and the researched phenomenon. We will conceive the findings into recommendations for pedagogical practice for teachers. Based on our research, we express the opinion that learning with digital technologies is more valuable than learning about digital technologies.

\section{References}

Arnott, L. (2017). Digital Technologies and Learning in the Early Years. London: Sage.

Batanero, J., Rueda, M., Cerero, J., \& Martínez, I. (2020). Digital competences for teacher professional development. European Journal Teacher Education, 43, 1-19. https://doi.org/10.1080/02619768.2020.1827389

Bus, A., Takacs, Z., \& Kegel, C. (2015). Affordances and limitations of electronic story books for young children's emergent literacy. Developmental Review, 35, 79-97. https://doi.org/10.1016/j.dr.2014.12.004

Gudmundsdottir, G., \& Hatlevik, O. (2017). Newly qualified teachers' professional digital competence: Implications for teacher education. European Journal Teacher Education, 41, 214-231. https://doi.org/10.1080/02619768.2017.1416085

Holloway, D., Green, L., \& Stevenson, K. (2015). Digitods: Toddlers, touch screens and Australian family life. M/C Journal, 18(5). https://doi.org/https://doi.org/10.5204/mcj.1024 


\section{Acta Educationis Generalis \\ Volume 12, 2022, Issue 1}

Jančaříková, K., \& Severini, E. (2020). Uses of augmented reality for development of natural literacy in pre-primary education. In Augmented Reality in Educational Settings (pp. 24-55). Leiden: Brill.

Kalaš, I., Kabátová, M., Brestenská, B., Gulaša, R., Chalachánová, M., Palúchová, K., Pekárová, J., Szarka, K., Vaníček, J., \& Winczer, M. (2013). Premeny školy v digitálnom veku. Prešov, Slovensko: Mladé letá.

Kasíková, H. (1997). Kooperativni učení, kooperativni škola. Praha: Portál.

Kaye, L. (2016). Young children in a digital age: Supporting learning and development with technology in the early years. London: Routledge. https://doi.org/10.4324/9781315752709

Kolláriková, Z. et al. (1997). Rozvoj kritického myslenia na základnej škole. Bratislava: Iuventa.

Kostrub, D. (2008). Dieta/žiak/študent - učitel' - učivo: didaktický alebo bermudský trojuholnik? Prešov: Rokus.

Kostrub, D. et al. (2018). Vychovávanie a starostlivost' o deti do troch rokov veku. Tvorba výchovného programu. Bratislava: Univerzita Komenského v Bratislave.

Kostrub, D., Severini, E., \& Rehúš, M. (2012). Proces výučby a digitálne technológie. Bratislava/Martin: Alfa print.

Kosturková, M., \& Ferencová, J. (2019). Stratégia rozvoja kritického myslenia. Bratislava: Wolters Kluwer.

Kotilainen, S., Suoninen, A., Walamies, T., \& Tuominen, S. (2011). Children's Media Barometer 2010: The Use of Media among 0-8-Year Olds in Finland. Helsinki: Finnish Society on Media Education. Retrieved from: http://mediakasvatus.fi/wp-content/uploads/2018/06/ ISBN978-952-99964-7-6.pdf

Lanna, L., Valente, R., \& Gómez, R. (2019). Aplicaciones educativas seguras e inclusivas: La protección digital desde una perspectiva ética y crítica. Comunicar, 27(2), 93-102.

Mešková, M. (2012). Motivace žáki̊ efektivní komunikací. Praha: Portál.

Murcia, K., Campbell, C., \& Aranda, G. (2018). Trends in early childhood education practice and professional learning with digital technologies. Pedagogika, 68(3), 249-264. https://doi.org/10.14712/23362189.2018.858

Reisoğlu, İ., \& Çebi, A. (2020). How can the digital competences of pre-service teachers be developed? Examining a case study through the lens of DigComp and DigCompEdu. Computers \& Education, 156, 103940. https://doi.org/10.1016/j.compedu.2020.103940.

Romero, T. R., Gutiérrez, M., \& Llorente C. M. (2019). Technology use habits of children under six years of age at home. Ensaio: Avaliação e Políticas Públicas em Educação, 27(3), 340362. https://doi.org/10.1590/S0104-40362019002701752

Romero, T. R., Sánchez, R., Cejudo, C., \& Rodríguez, C. (2020). The challenge of initial training for early childhood teachers. A cross sectional study of their digital competences. Sustainability 2, 12(11), 2-17. https://doi.org/10.3390/su12114782

Severini, E., Kožík L. B., \& Csandová, E. (2020). Uses of augmented reality in pre-primary education. In Augmented Reality in Educational Settings (pp. 3-23). Leiden: Brill.

Severini, E., \& Kostrub, D. (2018). Kvalitatívne skúmanie v predprimárnom vzdelávaní. Prešov: Rokus.

Sitná, D. (2013). Metody aktivniho vyučování. Praha: Portál.

Spitzer, M. (2014). Digitální demence. Brno: Host.

Štech, S. (1992). Škola stále nová. Praha: Univerzita Karlova - Karolinum.

Tóthová, R. (2014). Konštruktivistický prístup vo výučbe ako možnost' rozvoja myslenia žiakov. Bratislava: Metodicko pedagogické centrum.

Tóthová, R., Kostrub, D., \& Ferková, Š. (2017). Žiak, učitel' a výučba. Prešov: Rokus.

Undheimová, M., \& Jernesová, M. (2020). Pedagogical strategies of teachers in creating digital stories with young children. European Early Childhood Education Research Journal, 256271. https://doi.org/10.1080/1350293X.2020.1735743

Uváčková, I., Valachová, D., Lehotayová, B., Leginusová, T., \& Bruteničová, E. (2012). Oblasti edukačných skúseností detív materských školách. Stařeč: Infra. 